\title{
Endocrine disruptors and dental materials: health implications associated with their use in Brazil
}

\author{
Desreguladores endócrinos e materiais dentários: \\ implicações para a saúde decorrentes \\ de sua utilização no Brasil
}

Antonio Jorge Molinário Coelho 1

\footnotetext{
1 Pró-Reitoria Acadêmica, Universidade Severino Sombra. Rua Fernandes Júnior 89, Vasssouras, RJ 27700-000, Brasil. drmolinaro@mls.com.br
}

\begin{abstract}
This study analyzes international historical trends in the use of different types of materials in dental practice. The author describes the chemical properties of their ingredients and the potential and observed adverse effects in patients and dental technicians resulting from clinical or occupational exposure to various metals like beryllium, used to produce metal alloys. The growing use of various products (resin cements, ionomer cements, aesthetic restorative materials, resins, endodontal cements, and others) based on the compound bisphenol-A, whose chemical structure is similar to that of estrogen. Considering the demographic and contemporary work force characteristics of those involved in dental practice in the Brazil, the study highlights the possible effect of the use of these materials in both male and female patients and all age strata, as well as in health professionals with occupational exposure to products containing bisphenol-A.
\end{abstract}

Key words Dental Materials; Occupational Exposure; Endocrine Disruptors

Resumo Neste trabalho são analisadas as tendências históricas observadas, no plano internacional, quanto ao emprego das diferentes modalidades de materiais dentários na prática odontológica. São especificados as propriedades químicas de seus constituintes e os eitos adversos potenciais e observados em pacientes e técnicos de prótese, decorrentes da exposição ocupacional a metais diversos como o berílio, usado na confecção de ligas metálicas. Posteriormente, se analisa a transformação observada na prática odontológica, a partir da década de sessenta, com a introdução crescente de diversos produtos (cimentos resinosos, cimentos de ionômero, materiais restauradores estéticos, resinas, cimentos endodônticos, entre outros) à base do composto bisfenol A, com estrutura química apresentando similaridades aos hormônios estrogênicos. O trabalho destaca o possível efeito no Brasil, decorrente do amplo emprego desses materiais em pacientes de ambos os sexos e todas as faixas etárias, bem como em profissionais de saúde com exposição ocupacional aos produtos contendo bisfenol A, considerando as características demográficas e da força de trabalho contemporânea exercendo a prática odontológica no país.

Palavras-chave Materiais Dentários; Exposição Ocupacional; Desreguladores Endócrinos 
For many years, chemical properties were responsible for the selection of materials used in dental practice. This paradigm was already present in the primitive dental prostheses made by the Etruscans. Mechanical properties were decisive in the predominant use of dental restorations based on silver amalgam, described by G. V. Black (1896), from the early 20 th century until the mid-1980s. Proof of this trend is that the American Dental Association, one of the first associations to establish standards to specify the basic composition and properties of dental materials, published Guideline no. 1 in 1927 (Phillips, 1986). This standardization focused only on satisfactory mechanical properties for a given material to be used as a dental amalgam.

In addition, the reduced range of available techniques, technologies, and materials did not provide great options for dentists when they needed to restore a tooth. Until 1940, there were few materials available, and restoration of back teeth, where aesthetics was not a preponderant factor, was done with dental amalgam, a mixture of silver, tin, and mercury, or metal alloys containing a large amount of gold. The front teeth, where aesthetics is a major issue, were restored with acrylic resin (methyl dimethacrylate), a material to which dyes could be added, so that the restoration displayed a color similar to that of the restored tooth. In the case of partial and/or total losses, removable total and partial prostheses were made with rubbery material submitted to a vulcanization process. Polymerization techniques with these materials produced a very low conversion rate.

However, most of these materials displayed visible biological drawbacks. Dental amalgam showed clear signs of corrosion in the oral cavity, and it was common to observe spots and wear on the surface of restorations. Handling of the amalgam produces potential hazards for dentists and dental technicians, and mercury poisoning has been described extensively in the literature.

Due to the huge increase in the price of gold in the early 1970s, metal alloys containing large amounts of gold were replaced with base metal alloys.

Breakdown of these metal alloys releases various potentially harmful ions, like nickel, beryllium, copper, aluminum, chrome, tin, iron, and others into the oral cavity. Cases of toxic and allergic reactions associated with dental alloys have been reported frequently. However, cause and effect is very difficult to pinpoint in most cases, since the lesions may appear in areas distant from the oral cavity (es- pecially on the elbows, behind the knees, and around the waist).

A target for research relates to the materials used in prosthetic work with metal alloys that have to be machined before placing in the patient, a job done by technicians in the laboratory. Several researchers and manufacturers have called attention to and described numerous safety measures to avoid contaminating the air with potentially hazardous dust. For example, in a prosthetics laboratory one may detect beryllium fumes and dust resulting from machining, overheating during casting, and cutting without cooling.

Proper ventilation, dust evacuators at each workbench to keep dust from spreading around the workplace, and protective masks and goggles are indispensable items for developing a satisfactory work environment. Still, very few laboratories have any of this protective equipment, leading one to believe that technicians are exposed to significant levels of potentially hazardous prosthetic metals.

According to 1999 data from the Regional Dental Council of Rio de Janeiro, Brazil (Lima, 1999), there were 3,000 dental technicians registered with the Council, and approximately another 5,000 unregistered individuals with incomplete training who were working "clandestinely", according to data from the Rio de Janeiro Dental Technicians' Union (Jaime Leão Guttmann, personal communication). In Brazil as a whole, according to data from the São Paulo Dentistry Association, there are some 30,000 dental technicians (Teitelbaum, 2000). What health problems may already exist and have gone unreported in the literature that have resulted from non-compliance with biosafety and occupational health and safety standards? Is this not an issue for investigation by public health researchers and authorities?

As for metal alloys, research has already elucidated the phases that are most subject to corrosion and the effects of corrosion by-products on the body, even though such problems are largely ignored by health professionals in general.

The basic material for making total prostheses became methyl dimethacrylate, a thermosetting material that was more stable than previously used materials. Still, substances like plasticizers, binders, formaldehyde, and methyl dimethacrylate itself can be released into the oral cavity. The symptoms have been heavily reported in the literature and are easily demonstrated, since the patient presents an irritated, reddened area, generally corresponding to the contact area of the prosthesis and disappear- 
ing in a few days simply by interrupting use of the product.

Over time, acrylic resin, a methyl methacrylate-based polymer, proved to be inadequate as a restorative material. In addition to not providing satisfactory aesthetic results, dimethacrylate is highly toxic, leading to necrosis in a major portion of the teeth in which it was used.

The rubbery materials used in partial removable prostheses degraded very easily, releasing plasticizers, binders, and other substances, so that prostheses had to be remade after only a short period of use.

Observation of these facts and the resulting aggression to neighboring and remote tissues led researchers to emphasize the need for materials to have their biological properties tested before releasing them on the market, and that the results of such tests be decisive for their selection and use in dentistry (Richardson, 1997). Numerous in vivo and in vitro protocols were developed (Nathason et al., 1997). Currently, cytotoxicity, genotoxicity, potential toxicity, mutagenicity, and allergenicity tests, implants in guinea pigs, tests in large animals, and finally, clinical tests in human beings with wellcontrolled protocols and with at least five years' follow-up, form a reliable information base that clinicians can use to select the material to be employed in each specific situation, taking into account the mechanical and biological needs of each specific case. Dentists are increasingly capable of dealing with the problems generated by the breakdown of materials, although most such problems are difficult to observe clinically.

The 1960s witnessed a major change in dental technology, launched in 1956. Buonocore (1955) developed a technique in which dental enamel, which consists of $96 \%$ inorganic matter, hydroxyapatite, is etched for 60 seconds with $37 \%$ phosphorus. After the removal of the solubilized by-products with water jets, one observes that a fault pattern has been created in the enamel with a depth of up to $40 \mu \mathrm{m}$.

In 1962, Bowen developed a new resin, the BIS-GMA polymer, and a technique using the new material with acid etching (Bowen, 1962). After polymerization of the resin, a mechanical bond is created that is sufficient to provide the restoration with retention.

BIS-GMA is the product of the reaction between methacrylic and a bisphenol-A diglycidyl ether. The body of the molecule is similar to that of an epoxy resin, but the molecule's functional reactive groupings are acrylic (Figure 1).

Since BIS-GMA's mechanical, biological, and aesthetic properties were superior to those of previously used materials, there was a huge take-off in its use.

At first it was used only for small fillings in front teeth, where the forces generated during chewing are smaller. The favorable biological response, increased longevity of restorations, and huge aesthetic improvement led dentists to use this material in more and more clinical situations, so that both front and back teeth were restored with it.

The positive results achieved with BIS-GMA restoration led to an expectation by patients, who began to pressure dentists to further improve their aesthetic results, whatever the area to be restored. Amalgam and metal alloy restorations have been replaced by BIS-GMA-based resins, further increasing the use of this material.

Safety in the biological response, favorable handling properties, and different techniques in its uses (direct or indirect restorations, selfor light-cured), meant that BIS-GMA was employed in a wide variety of dentistry materials, including resin cements, ionomer cements, prosthetic crowns, aesthetic restorative materials, bonding agents, dentinal desensitizers, resins for temporary restorations, and endodontal cements.

BIS-GMA resin has been widely used to protect recently cut deciduous and permanent teeth. Covering such teeth with resin (sealant) isolates the dental enamel from the oral milieu, preventing the formation of caries. This technique became a mainstay for pediatric tooth decay prevention beginning in the early 1980s. Millions of children from all social classes had one or more teeth sealed, and the number of caries decreased sharply among populations adopting the sealing program.

Still, trust was undermined in the biological safety previously ascribed to BIS-GMA when a group of researchers reported the presence of bisphenol-A in the saliva of individuals using sealants (Ruse, 1997). Bisphenol-A (2,2bis (4-hydroxyphenyl) propanol) is considered a xenoestrogen, that is, a substance that produces a biological effect similar to that of a natural hormone, in this case progesterone. There is a growing debate on the involvement of xenoestrogens in a number of adverse effects, such as reduction in testicular size and sperm count and increased breast cancer rate. In vitro studies showed that concentrations greater than $25 \mathrm{nM}(0.0057 \mu \mathrm{g} / \mathrm{mL})$ display xenoestrogenic concentrations in cell cultures.

Since bisphenol-A is a precursor for BISGMA, and since the conversion rate is never $100 \%$, bisphenol-A can be released into the oral cavity. The study quoted above (Olea et al., 
Selected dental materials (methyl dimetacrilate, BIS-GMA and by-products) chemical structure.

Methyl dimetacrilate<smiles>C=C(C)C(=O)O</smiles>

BIS-GMA<smiles>C=C(C)C(=O)OCC(O)C(I)I(I)I</smiles>

Bisphenol-A diglycidyl ether<smiles>CC(C)(c1ccc(OCC2CO2)cc1)c1ccc(OCC2CO2)cc1</smiles>

Bisphenol-A - (BFA)<smiles>CC(C)(c1ccc(O)cc1)c1ccc(O)cc1</smiles>

Sources: Phillips, 1986; Ruse, 1997

1996) included 18 subjects. In each subject, 12 molars were sealed with a total of $50 \mathrm{mg}$ of light-curing sealant. The patient's saliva was collected during the first hour after insertion of the material. Mean concentration of bisphenol-A was $231 \mu \mathrm{g}$, ranging from 90 to $932 \mu \mathrm{g}$.

Various research groups, although emphasizing that the study was well-controlled, state that there is still no proof that bisphenol-A is really released in amounts that can harm patients using sealant. Other studies are needed to determine the level of harm to groups having contact with BIS-GMA, like dentists, dental technicians, patients from various age strata, and dental industry workers.

As of March 2000 there were some 180,000 dentists in Brazil, some $70 \%$ of whom were fe- male (Teitelbaum, 2000), and $80 \%$ of whom using BIS-GMA-based products daily (author's estimate).

There is great potential for problems such as an increase in the abortion rate among young dentists and dental technicians, since currently some $70 \%$ of dental school and dental technician graduates are women. Among men, theoretically there could be a drop in the sperm count, as well as a potential trend towards an increase in the testicular cancer rate, if a causal relationship is confirmed for occupational exposure to xenoestrogens.

Exposure to extensive amounts of sealants in young patients since the 1980s may have created the conditions for various adverse effects, such as early feminization and decreased 
testicular size. Another target group to be monitored for the incidence of these outcomes would be workers in the resinous materials manufacturing industry. With all these background, we believe it is time to launch studies on the possible harmful effects of occupational and clinical exposure to bisphenol-A.

\section{References}

BLACK, G. V., 1896. The physical properties of the silver-tin amalgams. Dent Cosmos, 38:965.

BOWEN, R. L., 1962. Dental filling material comprising vinyl silane treated silica and a binder consisting of reaction product of bisphenol and glycidyl acrylate. US. Patent N 3066, 112, Nov. 1962.

BUONOCORE, M. G., 1955. A simple method of increasing the adhesion of acrylic filling materials to enamel surfaces. Journal of Dental Research, 34:849.

LIMA, J. S., 1999. Editorial. Jornal ABO-Rio de Janeiro, 21.

NATHANSON, S.; LERTPITAYAKUN, P.; LAMKIN, M. S.; EDALATPOUR, M. \& CHOU, L. L., 1997. In vitro elution of leachable components from dental sealants. Journal of the American Dental Association, 128:1517-1523.

OLEA, N.; PULGAR, R.; PEREZ, P.; OLEA-SERRANO, F; RIVAS, A.; NOVILLO-FERTRELL, A.; PEDRAZA, V.; SOTO, A. M. \& SONNENSCHEIN, C., 1996. Estrogenicity of resin-based composites and sealants used in dentistry. Environmental Health Perspectives, 104:298-305.
PHILLIPS, R. W., 1986. Materiais Dentários de Skinner. 8a Ed. Rio de Janeiro: Editora Guanabara.

RICHARDSON, G. M., 1997. An assessment of adult exposure and risks from components and degradation products of composite resin dental materials. Human and Ecoligcal Risk Assessment, 3:683-696.

RUSE, N. D., 1997. Xenoestrogenicity and dental materials. Journal of Canadian Dental Association, 63:833-835.

TEITELBAUM, H., 2000. Editorial. Jornal ABO-Nacional, 12.

Submitted on 30 January 2001

Final version resubmitted on 4 October 2001

Approved on 23 October 2001 